Research Report No. 22/2008

\title{
International Institutions and Transnational Advocacy: The Case of the North American Agreement on Labour Cooperation
}

Ruth Buchanan

Osgoode Hall Law School of York University, rbuchanan@osgoode.yorku.ca

Rusby Mariela Chaparro

Follow this and additional works at: http://digitalcommons.osgoode.yorku.ca/clpe

\section{Recommended Citation}

Buchanan, Ruth and Chaparro, Rusby Mariela, "International Institutions and Transnational Advocacy: The Case of the North American Agreement on Labour Cooperation" (2008). Comparative Research in Law \& Political Economy. Research Paper No. 22/2008.

http://digitalcommons.osgoode.yorku.ca/clpe/198 


\section{Comparative Research in Law \& Political Economy}

CLPE RESEARCH PAPER 22/ 2008

\section{Ruth Buchanan \& Rusby Chaparro}

International Institutions and Transnational Advocacy: The Case of the North American Agreement on Labour Cooperation

EDTORS: Peer Zumbansen (Osgoode Hall Law School, Toronto, Director, Comparative Research in Law and Political Economy, York University), J ohn W. Cioffi (University of California at Riverside), Lindsay Krauss (Osgoode Hall Law School, Toronto, Production Editor) 

CLPE Research Paper 22/2008

Vol. 04 No. 05 (2008)

\title{
Ruth Buchanan \& Rusby Chaparro
}

\section{INTERNATIONAL INSTITUTIONS AND TRANSNATIONAL Advocacy: THE CASE OF THE NORTH AMERICAN AgreEMENT ON LABOUR COOPERATION}

\begin{abstract}
The North American Agreement on Labor Cooperation is studied as both a new type of arena for labor advocacy in North America, as well as a site that has fostered the emergence of new transnational networks of advocates. We locate our discussion in the context both of debates on the emergence and efficacy of 'soft law' in a diverse array of transnational contexts, a nascent literature on the globalization of public interest lawyering (PIL), as well as more long standing debates on transnational advocacy networks (TANS). The article provides an overview of the uses made of the NAALC complaints process between 1994 and 2005. While many of the early cases brought before the NAALC have been well documented, more recently, questions have been raised by some groups about the efficacy of the process. The article provides an in-depth consideration of two recent complaints, the first involving a proposed set of labour law reforms in Mexico, filed in the US $\mathrm{NAO}$, and the second involving the treatment of Mexican H2B (forestry) Visa workers in Idaho, filed in the Mexican NAO. It documents the advocacy networks developed in relation to each of these complaints, and the reasons why these particular networks turned to the NAALC process, notwithstanding the disillusionment expressed by a number of organizations that had filed complaints over the previous decade. While the advocates we spoke with were under no illusions about the likely outcomes of the complaints process itself, they sought to utilize it as a part of a wider range of strategies for publicity and social mobilization around their issues of concern
\end{abstract}

Keywords: NAFTA, NAALC, labor, public interest lawyering, transnational advocacy networks. 
JEL classification: K31, K33

Author Contacts:

Ruth Buchanan

Associate Professor, Osgoode Hall Law School, York University 4700 Keele St., Toronto ON, M3J 1P3

Email: rbuchanan@osgoode.yorku.ca

Rusby Chaparro

Ph.D. Candidate, Osgoode Hall Law School, York University 4700 Keele St., Toronto ON, M3J 1P3

Email: rusbsychaparro@osgoode.yorku.ca 



\title{
INTERNATIONAL INSTITUTIONS AND TRANSNATIONAL AdVOCACY: THE CASE OF THE NORTH AMERICAN AGREEMENT ON LABOUR COOPERATION
}

\author{
Ruth Buchanan and Rusby Chaparro*
}

\section{INTRODUCTION}

Economic integration facilitated by multilateral, regional and bilateral trade agreements over the past two decades has had a significant impact on the efforts of public interest lawyers everywhere. In the North American context, economic integration has been accompanied by an upsurge in the number of precarious workers in all three NAFTA countries, creating a growing demand for advocacy. At the same time, the North American Agreement on Labour Cooperation (NAALC) has emerged as an important new site for legal efforts on behalf of these workers. While the NAALC's significant limitations have hampered its effectiveness as an instrument of social change, its use over the past decade or more has facilitated the emergence of a more robust transnational community of labour advocates in North America. Our study of the NAALC will suggest that we need to broaden current conceptions of public interest lawyering if we are to understand both the paradoxical potential of the institution, and the way it has been utilized by advocates in all three countries.

The NAALC is notable in that it (along with the North American Agreement for Cooperation on the Environment-NAACE) is among only a

\footnotetext{
* Associate Professor, Osgoode Hall Law School and PhD Candidate, Osgoode Hall Law School. Many thanks are owed to Research Assistants Paula Barrios and Robert Russo, who each conducted significant amounts of research, including fieldwork, in an earlier stage of this project, as well as to Scott Cummings and Louise Trubek for comments on an earlier draft of the paper. The project was funded by a SSHRC Standard Research Grant. A SSHRC Small Research grant facilitated the final stages of the project. Finally, we would like to extend both gratitude and respect to the lawyers who shared their valuable time and insights with us.
} 
small handful of international institutions that expressly contemplate the participation of nongovernmental organizations. ${ }^{1}$ Both the NAACE and the NAALC provide adjudicative process open to both governments and nongovernmental groups for the investigation of complaints relating to failures of enforcement of environmental and labour standards in the NAFTA member states. ${ }^{2}$ Although the notion of non-state international associations participating in the creation and development of transnational norms is hardly new, it had long been confined to the informal realm.(Charnovitz, 2006) While activities such as the submission of amicus briefs to international tribunals and the monitoring of state compliance with international obligations by NGO's have become more common in recent years, these developments sit, sometimes uneasily, alongside traditional state-to-state mechanisms of international law. This expanded but somewhat indeterminate role for transnational advocacy organizations is part of the context in which the developments that this paper seeks to assess have taken place.

The NAALC (along with the NAACE-the North American Agreement on Environmental Cooperation) was drafted after most of the NAFTA text, largely as a vehicle for ensuring the passage of the NAFTA through the U.S. congress. ${ }^{3} \quad$ The NAALC does not create transnational standards for labour law, but commits each member state to enforcing its own labour laws. To this end, the NAALC sets out broad principles of labour protection that each member state pledges to promote (through its existing domestic labour law regime) and creates a set of institutions and procedures for facilitating the advancement of these principles including

${ }^{1}$ Other examples include the NAACE, the African Commission on Human and People's Rights, the World Bank Inspection Panel, and the UN Human Rights Commission. See Graubart, supra. Also, Jonathan Fox, (2000) “The World Bank Inspection Panel: Lessons from the First Five Years”, 6 Global Governance 279.

2 There are significant differences in the institutional structures created by the two agreements, leading some to observe that the NAACE goes farther along the path away from the traditional 'Westphalian' model of international law in two respects. It creates an international public advisory committee to provide independent advice to the Commission on Environmental Cooperation Secretariat. It also provides for citizen complaints to be filed with the CEC Secretariat directly, rather than with country offices as in the NAALC. See Knox, 2004.

3 For more detail on the initial assumptions regarding the agreement and details concerning its passage, see Robert G. Finbow, “The Limits of Regionalism: NAFTA's Labour Accord” (Ashgate: 2007); also Dombois et. al. (2003). 
the gathering of information, the fostering of cross border dialogue and the investigation of incidents of noncompliance through a complaint mechanism. ${ }^{4}$ At the time of its passage, it was widely criticized by NGOs and labour unions for its limited reach, lack of enforceable standards, and procedural complexity. Notwithstanding these profound limitations, the NAALC (along with the NAACE) does set up a 'citizen-petition' mechanism, whereby anyone can file a 'complaint' with one of the three National Administrative Offices (NAO) alleging that a member state is exhibiting a consistent pattern of violating its own labour, employment or health and safety laws.

This paper seeks to examine the use of the NAALC by transnational labour law advocates as part of a larger set of interconnected transformations within international institutions and among progressive lawyers. These two sets of developments; the emergence of new arenas for international advocacy and the creation of transnational advocacy networks, are so deeply interwoven that it is difficult, and indeed in our view, unhelpful to study them in isolation from one another. Advocacy efforts may contribute to the creation or the expansion of a particular institutional arena, as in the submission of amicus curiae briefs to the WTO Appellate Body. ${ }^{5}$ In turn, an institution's structure and processes can play a significant role in facilitating (or inhibiting) the creation of transnational networks around advocacy efforts, as our analysis of the NAALC will underscore.

In order to fully explore both the arenas and networks aspects of NAALC related advocacy, as well as their inter-relations, this article has two main sections. First, a theoretical context will be provided for both aspects of the analysis. Our discussion of the NAALC as a new type of transnational legal institution takes place in a broader context of debates on the emergence and efficacy of 'soft law' in a diverse array of transnational contexts. Our consideration of the transnational advocacy networks that have mobilized around the NAALC engages with a nascent

\footnotetext{
${ }^{4}$ The main institutions created by the NAALC are a governing Council comprised of the labour ministers, a Secretariat of international civil servants with a general mandate to support the council, and the three national administrative offices (or NAO's).

${ }^{5}$ Howse ref. Also could reference IISD submissions in the Methanex case leading to the decision that Amicus Briefs may be considered by ch. 11 panels in the NAFTA case.
} 
literature on the globalization of public interest lawyering (PIL) as well as more long standing debates on transnational advocacy networks (TANS).

The second part of the article turns to an examination of the uses made of the NAALC by advocates. Civil society actors play a vital role in the NAALC as they are the actors who identify and select the cases to be brought to National Administrative Offices, initiating the complaints process, that part of the institution around which most activity has circulated and which presents the greatest potential for fostering new forms of transnationalism. ${ }^{6}$ In this section, we first provide an overview of the use of the NAALC complaints process between 1994 and 2005. While the NAALC received a fair amount of scholarly attention early on and many of its first cases have been well documented, more recently, questions have been raised by some groups about the efficacy of the process. $^{7}$ We then look more closely at two of the more recent complaints, the first involving a proposed set of labour law reforms in Mexico, filed in the US NAO, and the second involving the treatment of Mexican H2B (forestry) Visa workers in Idaho, filed in the Mexican NAO. Our research is based on a review of secondary literature on the earlier NAALC cases, official documents filed with the National Administrative Offices, as well as interviews with lawyers involved in two of the most recent complaints. We are interested in documenting the advocacy networks developed in relation to each of these complaints, and in the reasons why these particular networks turned to the NAALC process, notwithstanding the disillusionment expressed by a number of organizations that had filed complaints over the previous decade. ${ }^{8}$ While the advocates we spoke with were under no illusions about the likely outcomes of the complaints process itself, they sought to utilize it as a part of a wider range of strategies for publicity and social mobilization around their issues of concern.

\footnotetext{
${ }^{6}$ States may also initiate complaints but for reasons discussed below, they never have.

${ }^{7}$ Articles and reports that document the earlier cases include Human Rights Watch, 2001, Compa, 2001, Schurtman, 2005, Graubart, 2005. Questions concerning the efficacy are raised by Delp et. al.

${ }^{8}$ On the disillusionment of a variety of unions with the NAALC process, see Stephen Clarkson, North American Governance, chapter on "Transborder Labour Governance”(forthcoming). See also Delp et. al, (2004).
} 
Our analysis will suggest that paradoxically, despite more than a decade of decidedly mixed results, it is too soon to dismiss the NAALC. Accounts that represent the NAALC as a 'toothless' and ineffective institution fail to grasp its hybrid role as a politicized mediator of social policy in the very unequal political economy of North America, that is, a “'legalized' political opportunity structure'.9 In design as well as practice, the NAALC is a complex and paradoxical institution. Although it contains both 'soft' (communication and cooperation) and 'hard' (committees of experts and sanctions) law features, state's concerns regarding its potential negative implications for trading relations have effectively precluded recourse to the 'harder' aspects of the agreement. Additionally, while it relies on civil society actors to initiate its complaints mechanisms, it gives them no further role in dispute resolution, frequently leaving them in the dark as to the eventual outcome. Notwithstanding ongoing frustrations with the process, however, complaints have continued to be filed in recent years (albeit at a slower pace). In the context of daunting economic and political inequalities among the three countries and significant linguistic and professional barriers between lawyers, unions and activists, the NAALC continues to play a role in fostering a nascent labour transnationalism within North America, whose significance should not be discounted. ${ }^{10}$

\section{FRAMING THE ANALYSIS: INSTITUTIONS AND NETWORKS}

As we suggest in our introduction, both aspects of the NAALC are equally relevant to an analysis of its import, both for the consideration of transnational public interest lawyering that is the subject of this special issue, as well as more generally for the future of North American labour policy. They are also, in practice, deeply interdependent. However, research on international institutions and transnational advocacy networks has for the most part proceeded along parallel tracks. While one of the

${ }^{9}$ Graubart, 2005.

10 Finbow, for example, notes "NAALC has generated unprecedented transnational interaction and integration among labour advocates, analysts and bureaucracies, stimulated by cooperative activities, and the transnational character of the submissions process.” p.220. 
aims (and potential contributions) of the current study is to move towards a more integrated analysis, we will begin by contextualizing each of these strands of analysis separately. These separate inquiries will provide the groundwork for our more detailed and integrated analysis of two recent complaints in the final part of the paper.

\section{A. THE NAALC AS A HyBRID LEgAL INSTITUTION}

The NAALC creates a set of institutions intended to facilitate regional cooperation within North America on matters of labour law and policy. It is governed by a council comprised of the Labour Ministers of the NAFTA signatories. It also creates a Secretariat of international civil servants with a mandate to support the Council. Each of the Labour Ministers is responsible for creating a National Administrative office in their respective territories. In the NAALC, unlike the institutions created at the same time to govern North American Environmental Cooperation (the NAAEC), it is the National Administrative Offices (NAO) that administer the complaints process. So, although the NAALC is comprised of both transnational and national elements, it has been the national offices, embedded within domestic bureaucratic structures and directly accountable to their governments, which have had the most influence in shaping NAALC's particular hybrid and politicized institutional form. The transnational role of the Secretariat has been less significant, both by design and in practice. ${ }^{11}$

The fact that the NAO's are effectively part of domestic bureaucracies makes their functions subject to the larger political calculus of the governments in question, including concerns about how the handling of particular complaints may affect overall relations between the countries. The political sensitivities of governments may also explain why information regarding complaints, or resulting Ministerial consultations, is not always readily available to the public. Ongoing bureaucratic

${ }^{11}$ The official website of the North American Commission for Labour Cooperation (www.naalc.org) states that "with the support of the Secretariat, the NAO's initiate the cooperative activities of the Commission, including seminars, conferences, joint research projects, and technical assistance in relation to the eleven Labor Principles of the NAALC.” (last visited on 1/11/08). 
reorganizations and changes of personnel, especially in the U.S. and Mexican offices, may have also contributed to ongoing problems of accessibility and transparency. Finally, the hybrid, politicized structure of the NAO's almost certainly also explains why recourse has never been made to the 'hard' law aspects of the agreement, such as the Evaluation Committees of Experts, Arbitral Panels or sanctions, on issues where they are available. $^{12}$

The U.S. NAO is housed within the U.S. Department of Labour. The office has experienced a series of recent changes. It changed its name to the Office of Trade Agreement Implementation (OTAI) in 2004, when the office was given further functions to include implementation of the labor chapters of bilateral and regional free trade agreements. ${ }^{13}$ The Director of this Office was also the Secretary of the National Administrative Office of the NAALC. A further name change occurred on December 14, 2006, to the Office of Trade and Labor Affairs (OTLA). This office maintained the designation of the NAO for the NAALC but was also given more functions in relation to other bilateral and regional free trade agreements (US-Australia, US- Chile, US- Morocco, USSingapore, and US-Dominican Republic-Central America (CAFTA-DR). ${ }^{14}$ This office combines the functions of the U.S. NAO and the Secretariat of the CLC, which means that complaints filed with other NAO's must also be filed in Washington prior to being processed. The reorganizations (which appear to be associated with significant reductions in funding) have dramatically affected the office's ability to discharge its functions effectively, which according to advocates skeptical of the Bush administration's commitment to labour rights, would have been their intended effect. Even the theoretically more independent and international

\footnotetext{
${ }^{12}$ See Dombois et al. (2003). ECE's may only be convened in relation to matters of occupational health and safety or other technical labour standards, not in relation to freedom of association, collective bargaining, or the right to strike.

${ }^{13}$ Department of Labor, Office of the Secretary, Bureau of International Labor Affairs; Notice of Renaming the National Administrative Office as the Contact Point for Labor Provisions of Free Trade Agreements; and Request for Comments on Procedural Guidelines. Federal Register / Vol. 69, No.246/ Thursday, December 23, 2004.

${ }^{14}$ Department of Labor, Office of the Secreatry, Bureau of International Labor Affairs; Notice of Reassignment of Functions of Office of Trade Agreement Implementation to Office of Trade and Labor Affairs; Notice of Procedural Guidelines, Federal Register Notice, Volume 71, No. 245, page 75591-76696, December 14, 2006.
} 
Secretariat has become dramatically less effective under the Bush administration; its credibility marred by political scandal, delayed appointments, and significantly reduced funding levels. ${ }^{15}$

The Mexican National Administrative Office functions in the Unit of International Affairs and reports directly to the Secretariat of Labour and Social Welfare. ${ }^{16}$ The current Director of the Secretariat is Jorge Rodriguez Castaneda, who was appointed on January 1 of 2007 by the current President. Both the Director of the Secretariat and the director of the Unit do not have much job security, given the political nature of their positions. Castaneda is a lawyer and has extensive experience in the area of telecommunications in bilateral negotiations with the US Department of State prior to his appointment. The employees of the NAO have been replaced with every change of government, but as of July of 2007 the changes had not been made, although they were expected at any time. ${ }^{17}$ The Mexican office has also changed its structure over time. For example, the operating manual for the office has been changed on the regular basis $\left(1997,1998,2001,2003\right.$, and 2005). ${ }^{18}$ These changes were aimed at organizing the committee of conciliators, the functions of the NAO and

${ }^{15}$ A review of the website in July 2007 reveals that the most recent Annual Report filed on the website dates to 2002; no events have been reported for several years and there only appears to be one permanent staff person. The credibility of the Secretariat was also recently marred by the abrupt departure of its Executive Director, Mark Knouse, in October, 2006. Mr. Knouse was appointed by U.S. Labour Secretary Elaine Chao to the post in 2004. Mr. Knouse is the husband of Secretary Chao's Executive Assistant and a former lobbyist. His departure came amid allegations that he had continued his lobbying activities while working for the Commission, had appointed many friends and associates to positions in the Commission, and had filed numerous false or excessive expense reports. "Allegations of Cronyism, Misdeeds, leave Labour Panel under a Cloud” Paul Singer, National Journal, October 31, 2006.

16 Secretaria de Trabajo y Prevision Social, Mexico, Estructura Organica at http://www.stps.gob.mx/transparencia07/estructuraorganica/organigrama general.htm Visited Mayo 14, 2007

${ }^{17}$ Telephone Interview with Patricia Juan Pineda, of the Frente Autentico del Trabajo (Labour Authentic Front). July 13/07. We can conclude, however, from the response issued by the office in October, 2007 to two complaints originally filed in 2005 indicate that the new appointments had been made.

${ }^{18}$ Camara de Diputados del H. Congreso de la Union, Manual de Organization General de la Secretaria del Trabajo y Prevision Social. Diario Oficial Publicado, January 19, 2005. P 4-6. 
modifying the goals of the office and the Secretariat. The Mexican office has fewer documents available online than either the U.S. or the Canadian office, and we found it somewhat difficult to obtain public documents relating to Complaint 2005-01. ${ }^{19}$ Indeed, although we were advised that an additional complaint had been filed in October, 2006, our searches revealed no record of it. $^{20}$

The North American Agreement on Labour Cooperation is frequently dismissed by its critics because it both fails to establish a transnational regime of labour standards for North America and lacks an effective enforcement regime. In our view, these types of critique aren't helpful because they don't recognize the potential utility of the 'soft' law aspects of the NAALC, nor do they acknowledge the complex balancing of political and legal mechanisms for the resolution of national and transnational issues of social policy that the NAALC represents. Substantively, the North American Agreement on Labour Cooperation does not seek to establish a transnational labour law for the continent of North America, nor does it set out any new labour rights or principles. It does, however, identify eleven core labour principles already recognized by the laws of all three countries and it commits the signatories to effectively enforce those domestic labour law regimes.

The NAALC also sets out a process for the adjudication of complaints arising from persistent or systematic failures of enforcement of domestic labour law. The process has a laddered, three step structure, with not all issues eligible to be taken through all steps. The first step involves Ministerial Consultations, invoked on the basis of an alleged consistent failure by one of the member-states to enforce its domestic labour laws (associated with any of the eleven labour principles identified in the

\footnotetext{
${ }^{19}$ Although fieldwork for the larger study has also been completed in the Canadian NAO, for the purposes of this paper, we are confining our discussion to the U.S. and Mexican sites.

${ }^{20}$ Telephone Interview with Patricia Juan Pineda, July 13/07. Ms. Pineda stated that she had been given no filing number and that later she was advised that the complaint may have been lost when it was sent on to the Secretariat in the U.S, as the U.S. office was in 'transition'. This was a complaint relating to limitations on collective bargaining rights in the state of North Carolina.
} 
agreement). ${ }^{21}$ A second step could be the convening of an Evaluation Committee of Experts (ECE). This step may not be invoked, however, for complaints pertaining to freedom of association, the right to collective bargaining and the right to strike, arguably, the most fundamental (but also the most political) of the labour rights identified by the Agreement. The final step would involve establishing an Arbitral Panel, which could have the capacity to levy trade sanctions. This step could only be invoked in relation to three areas of labour rights: child labour, minimum wages or occupational injuries/illneses. Not surprisingly, in our view, no government to date has sought to invoke the sanction process.

When the administration of these processes was being set up, it was determined that complaints may not be filed against a country in its home office. While one might speculate as to the possible rationales for this administrative decision, it has had one very significant and unanticipated effect on the unions, social movements and other advocacy groups who have sought to use the complaints mechanism. (Kay, 2006:16). As a practical matter, this requirement means that the activistlawyers working on a complaint need to collaborate at least to some degree with lawyers or groups in another country. As we will discuss below, the transnational advocacy networks that have been formed around the filing of various NAALC complaints have become one of the NAALC's most notable achievements.

In reviewing a citizen-petition, the NAO commissions legal studies, receives information from any interested party including the complained of government, then issues a report with its findings and recommendations. There are no formalized procedures or set timetables for the submission process, which has been an issue for advocates who have sometimes found themselves required to respond to material submitted by companies or governments on short notice or not at all. The most an NAO Report can do is to recommend follow up consultations between member governments. The involvement of the petitioners usually

${ }^{21}$ The identified labour principles are as follows: freedom of association and the right to organize, the right to bargain collectives, the right to strike, the prohibition of forced labour, labour protections for children and young persons, minimum employment standards, the elimination of employment discrimination, equal pay for women and men, the prevention of occupational injuries and illnesses, compensation in cases of occupational injuries and illnesses, and the protection of migrant workers. 
ends at this point, as there is no requirement that they be informed of the substance, timing or outcomes of Ministerial Consultations. This is a well remarked upon source of frustration for petitioners who, having received a strong affirmation in a NAO Report, may then wait years without any information or further evident progress, while the complained of working conditions continue, or the impugned company closes the plant and relocates elsewhere. (Schurtman, 2005) As we've already suggested, however, measuring the NAALC's success or failure in terms of concrete measurable results in specific cases runs the risk of seriously underestimating its value.

That is, as our review of its institutional framework has revealed, the NAALC was neither designed for nor intended to provide an enforceable North America-wide regime of labour standards, instead, it offers a hybridized mechanism that utilizes a number of 'soft law' processes that are likely to be more familiar to students of European social integration than North American labour lawyers. ${ }^{22}$ In contrast to command and control style regulation with its binding enforcement mechanisms, the more flexible 'soft law' model incorporates such practices as the issuance of reports, consultations, monitoring, information exchange and expert reviews. Scholars have argued that soft law is a distinct regulatory form, which operates in conjunction with more traditional regulatory models in a variety of ways. (Trubek and Trubek, 2007). Soft law mechanisms function differently from other forms of regulation, changing behavior of regulated actors indirectly, such as through exchanges of information and best practices, using persuasion and publicity (rather than sanctions) to encourage poorer performers to improve.

Although the evidence suggests that NAALC complaints have rarely resulted in measurable changes to working conditions at particular worksites, the publicity that surrounds especially critical NAO reports, especially when combined with effective mobilization, can create political pressure for member state governments. And labour and social movement advocates in North American have, for the most part, utilized this mechanism to strategically advance their own ends. Nonetheless,

${ }^{22}$ See generally Trubek and Trubek, 2007. Also, Anna di Robilant, "Genealogies of Soft Law” (2006) 54 American Journal of Comparative Law 499. 
advocates continue to have questions concerning the efficacy and efficiency of the process. In part, this is because more needs to be understood about the ways in which legal advocacy may couple with-- to facilitate or constrain --political campaigns in different countries. Member governments are likely to be differently susceptible to such pressures, and their susceptibility may vary considerably over time as governments change. It has been observed, most recently by Cynthia Estlund in an article on the 'ossification of American labour law', that United States legal institutions and decision-makers have been very resistant to the idea that international or in this case, regional norms might provide a model for domestic legal changes. ${ }^{23}$ This might be contrasted with the European context, where there is evidence to suggest (although it is still debated) that domestic labour regimes have been positively influenced from the regional level through the 'soft law' methods of the European Employment Strategy. (Trubek and Trubek, 2005) Of course, there are many important differences between the highly developed and institutionalized form of economic and social integration in Europe and the truncated neo-liberal North American approach. Moreover, in either context, the 'success' of soft law reforms can be notoriously difficult to assess. $^{24}$

Even so, it can be observed that the 'soft law' of the NAALC to date has had considerably less purchase (than the EES). The lack of procedures for filing and response times, transparency, and reporting requirements, combined with the fact that NAO's are embedded within national bureaucracies, has made it particularly susceptible to political pressures. Complaints that are framed in potentially more transformative terms - that is, those which seek to gain rights for workers to enable them to become more powerful on their own terms, are particularly vulnerable. In recent years, the inhospitability of the Bush administration to labour rights has added another major obstacle for advocates in both countries seeking to use the NAALC, and use of the process has dropped off precipitously as a result. Advocates with experience in the system have become disillusioned, suggesting that NAALC complaints may not be

\footnotetext{
${ }^{23}$ Cynthia Estlund, (2002) “The Ossification of American Labour Law” Columbia Law Review 1589.

${ }^{24}$ Trubek and Trubek.
} 
worth the enormous amount of time and energy that they consume. (Schurtman; 2005; Delp, 2004; Graubart, 2005) ${ }^{25}$

One key question addressed by the current research is why and how some advocates continue to find more than marginal utility in utilizing the NAALC complaints mechanism. We suspect that both expectations regarding outcomes and styles of advocacy have to be adapted to the NAALC's unique institutional form. While for some advocates, persistent and profound power differentials and increasingly inhospitable domestic political contexts provide reasons to turn to other venues and/or projects, others continue to find ways to make use of the admittedly limited opportunities provided by the NAALC while working towards a more transformative model of transnational labour regulation, such as Rodriguez-Garavito's "empowered participatory labour regulation" (EPLR) or Trubek and Compa's 'transnational labour law' (TLL) ${ }^{26}$ Our review of the use of the NAALC in the second part of this paper, and particularly, in relation to several of the more recent cases, will offer some insights into the ways in which advocates continue to strategically utilize the NAALC complaints mechanism. Before turning to that discussion, however, we will provide some context for the networks aspect of our analysis.

\section{B. STUDYiNG TRANSNATIONAL LABOUR ADVOCACY NETWORKS IN NORTH AMERICA}

One well-documented consequence of the NAALC almost from its inception has been the facilitating role it has played in fostering transnational networking among unions and labour rights activists in the three countries (Compa; 2001,2005). This is in sharp contrast to the situation prior to the NAALC, where there was distance and even distrust between unions in the U.S. and in Mexico. (Kay, 2006) The

\footnotetext{
${ }^{25}$ In contrast to the others, Graubart counsels a wait and see approach, suggesting that the 'political opportunity structure' of the NAALC may become more potent when the political winds shift. We are less sanguine about the possibility of meaningful political change in the short term, and so our emphasis in this paper is different. We seek to ask what use advocates can make of the NAALC in difficult times such as these.

${ }^{26}$ Rodriguez-Garavito, 2005: 211; Trubek and Compa 2005: 223.
} 
noteworthiness of this shift is evidenced by a considerable amount of useful scholarly attention that it has received. Although there are a number of very good recent studies of North American union and NGO networking in the wake of NAFTA (Kay, 2006; Hertel, 2006; Graubart, 2005; Anner and Evans, 2004), we are of the view that two lines of questioning might explored further. Firstly, in the context of this special issue on the globalization of public interest lawyering, we are interested in addressing questions specific to the transnationalization of activist lawyering practices themselves (Cummings, 2007). By lawyering practices, we mean questions such as how decisions to bring forward particular complaints are made, how evidence is gathered, how differences in language and legal systems are negotiated, how complaints are drafted and by whom, and how the legal complaints are coordinated with political struggles in several countries. Another set of questions that we would add to these emerges from some of the more recent literature on transnational advocacy networks (TANS) which raises important concerns about the dynamics or 'mechanisms' operating within transnational networks, including questions concerning power differentials between differently situated 'partners'. (Hertel, 2006; Rodriguez-Garavito, 2005; Ansley, 2005)

The question of translation is an important one to engage with when we are approaching the difficult questions involved in the mobilization of people across divides of nationality language, and culture. It is no less an issue in relation to public interest lawyering. While there is no direct translation into Spanish of 'public interest law', there is a vibrant tradition of 'alternative uses of law', which is not exactly the same thing. (Rodriguez-Garavito, 2005, Borrero, 1995; Laso Prieto, 2007) While 'public interest law' has largely been understood in the US in terms of court based litigation strategies, 'alternative uses of law' embed legal critical activism within broader debate and political mobilizations. ${ }^{27}$

${ }^{27}$ The notion of "Uso Alternativo del Derecho" was first introduced in Italy in 1972 in Criminological studies, from where it permeated the European Civil law countries, especially Spain, and from there to become an acknowledged approach in the Latin American legal systems. This could be considered a neo-Marxist theory, as it intended to bring citizens closer to what had been considered the dominant and abstract legal institutions. The alternative use of law is based on the idea that law is to be understood in relation with the political and economic system that surrounds it, rather than just an abstract system. As such, law itself is a deemed as a political institution in the sense that 
However, along with the economic integration driven by NAFTA and other globalizing institutions, it may be that these two traditions are becoming somewhat less distinct.

Cumming's (2007) comprehensive analysis of the internationalization of U.S. public interest lawyering suggests that internationalization has significantly changed the landscape of advocacy, "altering the strategic value and applicability of different tactical options, multiplying the venues for legal engagement and creating possibilities for new professional alliances." The effect has been a shift in emphasis to "multi-faceted advocacy over narrow legal representation". Law, though still important, is coming to be understood as an increasingly limited tool for social change. This is a significant shift for most public interest lawyers in the U.S., where the focus, at least of the scholarly literatures on legal mobilization, has long been on the courts and the use of litigation by outsider groups seeking social change (Rodriguez-Garavito, 2005; Scheingold and Sarat, 2004). ${ }^{28}$ Cumming observes that global interdependence has expanded "the scale of advocacy in ways that challenge the traditional conception, narrowing routes of legal redress while simultaneously expanding opportunities for new political collaborations and strategic approaches.”(p. 81) He identifies shifts in three key areas; the goals public interest lawyers pursue, the tactics they deploy and the professional roles they assume. Our research on the NAALC provides some evidence for each of these shifts on the part of public interest lawyers in the U.S., incorporating some insights into the role of 'alternative uses of law' in these transformations. Overall, in the NAALC context, our study (along with several others) documents the emergence of a highly politicized style of advocacy, one that is

it allows for political transformations, but the duty to make those transformations happen is given primarily to lawyers, or in any case, to those "operating" or dealing with law whether by interpreting, enforcing it or adjudicating particular cases and also to citizens who are the ultimate addressees of the law.

${ }^{28}$ As Cummings puts it "Public interest lawyers, of course, have long viewed legal rights as supportive of-rather than oppositional to-political mobilization. Indeed, the classical objective of public interest law is framed in terms of remedying the deficiencies of majoritarian democracy by opening political institutions to participation by underrepresented social groups.” (p. 82) But, one must not overlook the existence within the U.S. of a critical tradition, which has long warned against the overestimating the power of law to effect social change. See Lobel, 
collaborative, engaged and embedded in the ongoing struggles of social movements. ${ }^{29}$

Both an 'institutional' and a 'network' dynamic seem to be at work in this shift. Firstly, advocates from both countries are well aware of the large role that diplomacy plays in the decision-making in the NAO's, with offices in each state being careful not to place too many demands on other governments, as a preventive (and defensive) measure in case of future complaints that may cause them difficulties. In this way, the NAALC is typical of many such transnational fora, where politics and law intersect in complex ways. ${ }^{30}$ Rather than looking for specific legal outcomes, advocates turn to the NAALC in order to bring to light and to denounce systemic violations that have been ignored by governments. Secondly, as these lawyers work together on drafting complaints, discussing strategies and coordinating their efforts with social movements and unions on both sides of the border, they are learning from each other, not only about the law or the subject of the complaint, but also about lawyering practices, and advocacy more generally. So, at the same time as lawyers are using the NAALC as a vehicle to focus public attention on the need for a new dialogue between workers, advocates, grassroots groups and institutions, they are themselves beginning to engage in it.

These lawyering networks also seem to fall within what Keck and Sikkink's pioneering work (1998) identified as 'transational advocacy networks'. The wealth of scholarship that has recently examined Transnational Advocacy Networks (TANS) has documented the ways in which local advocacy efforts in developing countries can gain profile, publicity and political purchase through connecting to broader transnational networks; what Keck and Sikkink call the 'boomerang' pattern of influence. Certainly, some of this is going on in the NAALC context. However, much of the early research on TANs focused on human rights (civil and political) and environmental advocacy, and may have

\footnotetext{
${ }^{29}$ See also Graubart,

${ }^{30}$ It is important to note Rodriguez-Garavito's caution, however, against a narrative that represents 'soft law' as a replacement for hard law, or locates it in a 'paradigm shift' from 'regulation to governance.' As he observed in the context of the struggle over corporate codes of conduct and the monitoring of labour standards in the apparel industry, "the hardness of international labour standards is in and of itself a key object of contention between TNC's and their critics”. 2005a, p. 77.
} 
glossed over some of the challenges and difficulties of these networks. (Riles, 2007)

As Fran Ansley reminds us, building cross border alliances is never easy. $^{31}$ It is important to be attentive to questions of differences arising among differently situated workers, social movements and advocates. Recently, as some scholars have begun to build bridges between research on transnational advocacy networks (TANS) and social and economic rights, we have begun to see more nuanced accounts of the conflicts and power dynamics within these networks. In the North American labour context, several established international human rights organizations, including Human Rights Watch and the International Federation for Human Rights, have been involved in investigations and campaigns against labour rights violations in Mexico. (IFHR, 2006; Human Rights Watch, 2001) However, international rights organizations and local grassroots groups may not always see the issues involved in a particular campaign in exactly the same light, as Hertel (2006) has documented. Her account revealed the mechanisms by which local activists worked within but also contested the campaign mounted by Human Rights Watch against pregnancy testing in the maquiladoras. While HRW consistently framed the issues in terms of 'discrimination,' local activists saw the issues as relating more broadly to social justice questions in the maquiladoras. Rodriguez-Garavito's study of transnational anti-sweatshop campaigns and the effectiveness of various third party monitoring schemes also reveals the importance of attending to the ways that power asymmetries in NGO networks may derail the transformative potential of advocacy.

\section{PUTting THE NAALC TO WORK: LEGAL ADVOCACY AND LABOUR TRANSNATIONALISM}

\footnotetext{
${ }^{31}$ Ansley 2005 p. 170-171 He argues that the differentials in social and economic conditions between the collaborators from the North and the South make it difficult for those groups of the North to "move toward genuine peer-to-peer alliances" with their counterparts from the South.
} 
We now turn to a closer examination of the use of the NAALC by labour advocates. ${ }^{32}$ That examination has three components: an overview and analysis of NAALC complaints, a more detailed account of two recent complaints and a summary of our findings. The overview allowed us to identify a number of salient issues arising from the dynamic interaction of the institutions of the NAALC and the evolving advocacy networks that have sought to utilize the NAALC processes which we were then able to probe more deeply in our investigation of the two recent cases.

\section{A. OVERVIEW AND ANALYSIS OF THE NAALC COMPLAINTS PROCESS}

Although it was criticized from the outset by labour leaders for creating lengthy and complex procedures that lack enforceability ${ }^{33}$, the NAALC's complaints process has been relatively well used since its inception in 1994. We will argue that the formal complaints process, although not without serious limitations, needs to be understood as embedded within a complex and ongoing series of formal and informal communications between governments, the public, unions, workers, and advocacy organizations in all three countries. With the exception of the year 2002, complaints have been filed each year from 1994 to 2006, amounting to thirty-five complaints in total. As some had predicted, the Mexican state has become the main target of NAALC complaints. Twenty two have been filed against Mexico, followed by eleven against the US and just two against Canada. ${ }^{34}$ In our overview of the thirty five

${ }^{32}$ In this analysis, we are focusing on complaints filed in the U.S. and Mexican NAO's. While research has been done in the Canadian NAO for the larger study, we have not included it here.

${ }^{33}$ See for example Tom Barry et al, (1994) The Great Divide: The Challenge of U.SMexico Relations in the 1990’s 323-26.

34 Thirty-five submissions were filed under the North American Agreement on Labor Cooperation (NAALC) between 1994 and 2006. Twenty one were filed with the U.S. National Office, nineteen of which involved allegations against Mexico, while the two remaining involved allegations against Canada. Nine submissions were filed with the Mexican NAO, all of which contained claims against the US. Five submissions were filed with the Canadian NAO, three of which include allegations against Mexico and two against the US. Of the submissions filed to date with the U.S. NAO, four (940004, 9602, 
complaints, however, we noted significant shifts over time in a number of areas: the frequency of use, the nature of complaints filed, the actors involved, and the response of the NAO's. Because of the relative underutilization of the Canadian office, we have focused our analysis primarily on complaints filed in Mexico and the US.

In terms of the frequency of the use of the complaints process, we identified three moments in the history of NAALC: rise, peak and decline. The rise occurred during the first four years of its existence, when advocates, still exploring the mechanism, filed between one to four complaints a year and preferred the US National Office for processing the complaints - eight complaints were filed with the US office, and one was filed with the Mexican equivalent. ${ }^{35}$ The peak happened in the year 1998 during which advocates became more aggressive and explored possibilities in the three National Offices with the filing of ten complaints -four with the US NAO, four with the Mexican NAO and two with the Canadian office. A decline in the filing of complaints began in 1999. Since that time, only eight complaints have been filed with the US NAO, four have been with the Mexican NAO and three with the Canadian office. $^{36}$

9803, and 2004-01) were withdrawn by the submitters before hearings were held or the review process completed. Hearings were held on ten (940001, 940002, 940003, 9601, 9701, 9702, 9703, 9901, 2000-01, 2003-01). Eight of the U.S. submissions (940003, 9601, 9701, 9702, 9703, 9901, 2000-01, 2003-01) have gone to ministerial-level consultations. The U.S. NAO declined to accept submissions 9801, 9802, 9804, 2001-01, and 2005-01 for review. Eight were filed with the Mexican NAO and involved allegations against the United States. Mexican NAO submissions 9501, 9801, 9802, 9803, 9804 resulted in ministerial consultations. Four submissions have been filed in Canada, two raising allegations against Mexico and two raising allegations against the United States. Canadian NAO submission CAN 98-1 resulted in

${ }^{35}$ Seven, out of eight complaints challenged the Mexican government, but the complaints were led by US-based submitters. The complaints US 940001, US 940002 (Honeywell \&General Electric), US 940003 (Sony), US 940004 (General Electric), US 9601 (SUTSP), US 9602 (Maxi-Switch), US 9701 (Gender Discrimination), US 9702 (Han Young), US 9703 (Itapsa), and MEX 9501 (Sprint).

${ }^{36}$ While in 199810 complaints were filed with the various offices, 2 were in 1999, 1 in 2000, 2 in 2001, 3 in 2003, 1 in 2004, 5 in 2005 (3 with the US, 1 with Mexican, and 1 with Canadian) and 1 in 2006 (with the Mexican Office). 
Looking at the substantive issues raised by the complaints is essential to understanding both the institutional response and the transformative potential of the NAALC mechanism. In the identification of those substantive claims, one is to be reminded of the distinction presented by Professor Rodriguez-Garavito (2005:205) between what the calls 'protective' and 'enabling' rights. The narrower claims, which have more overlap with conventional civil and political rights, correspond with the 'protective' category, while 'enabling' rights are those relating to collective bargaining, freedom of association and the rights to strike. The latter, according to Rodriguez-Garavito, are potentially more transformative because they facilitate workers power to continue to participate in their own struggles. The majority of the complaints, twentyfive, invoke this latter category, and they have played a most significant role in shaping both the role of advocates and the institutions response during the history of the NAALC. ${ }^{37}$

Among the complaints involving freedom of association, we found that, perhaps for strategic reasons, advocates did not always frame the claims in the same way. Twelve of these complaints sought protection of that collective right as a unique claim (US 940001, US 94002, US 940003, US 94004, MEX 9501, MEX 9601, US 9602, US 9803, US 9804, CAN 9901, US 2005-02, and CAN 2005-01), while the other thirteen included the protection of freedom of association as a claim connected to rights such as to occupational health, non-gender based discrimination, minimal employment standards, child labor prevention or collective bargaining (US 9702, US 9703, CAN 9801, MEX 9801, MEX 9802, US 9901, US 200101, MEX 2003-01, US 2003-01, CAN 2003-0, US 2005-01 and US 200503) and strike (US 9801, US 2005-01 and US 2005-03). We found that the presence of collective rights claims became an indicator of the institutional response to particular complaints. Those complaints which solely addressed freedom of association did not travel very far, while those solely involving social or economic rights had a better chance to advance

\footnotetext{
37 The remaining nine complaints were proposed in isolation from collective rights' protection. In those submissions, advocates sought protection of various fundamental, civil and economic rights including minimal employment standards (CAN 9802, MEX 9804, MEX 2005-01, MEX 2006-01), restriction on child labor (US 9802), protection of migrant workers (US 2005-01), occupational health (MEX 2001-01, US 200401), and eradication of discrimination in the work place (US 9701).
} 
several steps in the process and those with mixed claims were sometimes advanced, but solely with respect to the civil, social or economic rightsrelated claims.

In its initial few years, labour advocates saw the NAALC as a vehicle for highlighting the suppression of independent unions in Mexico and the poor conditions in maquiladoras owned by US firms. Indeed, during the first year of NAALC (1994) four complaints were filed with the US National Office against the Mexican state, alleging violations to freedom of association. The first two cases, known as Honeywell and General Electric (2 complaints) focused on disputes over organizing drives in Mexican factories that predated the NAALC's existence. ${ }^{38}$ This trend continued during the two subsequent years. ${ }^{39}$ As expected, these complaints generally did not advance institutionally as expected by labour advocates. Although the earliest two complaints were accepted for review, the public report stated that Mexico had not failed to enforce its own relevant laws. Two of the subsequent complaints (US 9404 and US 9602) were withdrawn by the submitters before the review of the claim, as the issues raised in the complaint were resolved during the process. And the other three claims reached ministerial consultation, which ended in commitments among the three National Administrative Offices to implement educational activities involving public seminars, forums, conferences, expert's reports, meetings and exchange of information regarding national legislation.

In cases filed during the middle period, increasingly sophisticated and networked groups of advocates focused the complaints on occupational health, discrimination and safety claims, as the NAALC contemplated the possibility that these types of claims could be taken beyond Ministerial consultations. As these submissions involved more discrete 'protective' rights and the institutional response was more welcoming. That was the case of submissions US 97-01, 97-02, 97-03, CAN 98-1, CAN 98-2, MEX 9801, 9802, US9901, US 2000-01, MEX

\footnotetext{
${ }^{38}$ These two complaints are also known as US 940001 and US 940002.

${ }^{39}$ In 1995, a complaint was filed with the Mexican office against the US state alleging violation of freedom of association (MEX 9501 or Sprint), and in 1996 two cases were filed with the US office against Mexico (US 9601 and US 9602). During the three early years, seven complaints regarding freedom of association were filed with the US and Mexican National Administrative Offices.
} 
2001-1, 2003-01 (ongoing) and 2005-03 (awaiting report). Ministerial consultations were held in these cases and they led to compromises in terms of educational programs on occupational health, safety in the work place, environment, migrant worker's rights and exchange of information among the three offices. In the CAN 98-01 case, the issues raised in the submission were resolved following the assistance and participation of a government team of experts on safety, health and labor environment. Also notable is the use of experts in the resolution process, which contrasts with the more informal negotiated approaches associated with collective rights claims.

More recently, the submissions have related to what we might describe as structural deficiencies in labour market governance. Particularly in the US and Mexico, advocates have begun to demand interpretation of local laws through the lens of international labor standards, and have raised questions of public policy and even challenged proposed law reforms. This approach attempts to broaden the scope of the NAALC, which as observed earlier, is meant to only promote the enforcement of domestic laws. Several recent cases have related to the failures of the US to extend its labor laws to migrant workers from other countries, particularly Mexico. Parallel to this turn in the action of advocates, the institutional response has slowed notably.

Cases that illustrate this turn notably include the MEX submission 9802 (Apple Growers) which highlighted the difficult circumstances of migrant workers working seasonally as apple pickers in Washington State. The Apple Growers case involved a very broad coalition of advocates with considerable experience in NAALC cases. $^{40}$ Other illustrative cases include MEX submission 2003-01 (North Carolina or H-2A Visa Program) seeking protection of collective rights, health and safety, minimal labor standards, discrimination and protection of migrant workers; US 2005-01 (Labor Law Reform) which sought to stop the approval of a Labor Law Reform in Mexico under the argument that the government bill was intended to codify systemic violation of collective rights including freedom of association, collective bargaining and strike and also social and political rights; US 2005-02 (Mexican Pilots-ASPA) which sought protection of collective rights of pilots by arguing that the

${ }^{40}$ The Apple Growers case has been usefully discussed in Compa, 2001. 
Mexican government failed to enforce its own laws in accordance with international labor conventions, the national constitution, and the principles of the NAALC; US 2005-03 (Hidalgo), which alleged violations of collective and individual rights of workers of the textile industry by the Mexican government, alleging that the government failed to enforce its law with respect to equitable and transparent labor tribunal proceedings; MEX 2005-01 (H-2B Visa Workers) related to the precarious situation of migrant workers in Idaho, and the MEX 2006-01 (State of North Carolina) which sought protection for the collective bargaining rights of government employees in the state of North Carolina under the argument that the state failed to follow International Conventions, the NAALC, and principles of international law. ${ }^{41}$

In contrast with the relatively prompt and active institutional responses observed in the earliest stage of the NAALC, in all recent submissions the institutional response has been slow and convoluted. In these cases, the National Offices took somewhere between five months to over fifteen months to accept or reject the review of the claims -as in the H-2B visa workers' case- and between fifteen months to two years to produce a final action or at least a final agreement or compromise between governments. In some of the cases there was no final decision even after several years. Timing is not the only concern. Although transparency is a principle affirmed by the NAALC text, the NAO's are failing to keep the complainants apprised of their processes and are refusing to release information to the public, including final decisions and compromises of the signatories. In submission MEX 2006-01 against the State of North Carolina, for instance, the complaint was in fact lost. According to one of the lawyers involved in the case, the complaint was filed with the Mexican office in October of 2006, but ten months later, it was not possible to obtain any information about the submission. ${ }^{42}$ Another example is that of the submission on the Labour Law Reform. Despite the fact that the decision declining the review of the submission was issued on January 21

\footnotetext{
${ }^{41}$ While most of the submissions are available online in the NAALC's information system, this latest is not even mentioned. We, however, obtained a copy of it from the team of submitters. According to Patricia Juan Pineda, this last complaint went lost in the Mexico office at least until July of 2007.

${ }^{42}$ Interview with Patricia Juan, July, 2007.
} 
of 2006, it has not yet been released to the public. ${ }^{43}$ And, finally in terms of outcomes, seen in the context of the NAALC's objectives, this era has been the most disappointing. Either there has been no response, as in the North Carolina complaint, the NAO has declined to review issues focused on collective rights (cases of ASPA, Mexican Law Reform) or where the case has been accepted for review, determinations are unduly delayed (Hidalgo and H-2B Visa Workers).

The final element we were able to assess in our overview is the number of named complainants. While the qualitative aspects of the networking process were of greatest interest to us and will be discussed below, it was possible to observe a quantitative shift in networking activity through the increase of numbers of listed complainants over time. In the first year the complaints exhibited just one, one, one and five submitters and between 1993 and 1999 the complaints had between one and five (one just one occasion) submitters. However, the practice of involving wider networks of groups appeared to take off around 2000. One particularly well coordinated effort that year involved twenty three organizations (Auto Trim/Custom Trim). ${ }^{44}$ More recently, in 2005, one complaint was signed by 23 submitters (Mexican Law Reform), another one was cosigned by 12 (H-2B Visa Workers) organizations and in 2006 the only complaint was submitted by 55 organizations (State of North Carolina Employees). Further, the listed complainants and participants in the preparation and process not only include lawyers and organizations from the three NAFTA countries, but also unions and human rights organizations from other latitudes including Asia and Europe (Mexican Law reform and North Carolina Employees). How the various groups and organizations work with each other within these networks, and what role the practice of widening the 'net' in relation to given complaints plays in the overall strategy of the advocates, are questions that remain to be considered in more detail in relation to particular complaints. We will now turn to that discussion.

\footnotetext{
${ }^{43}$ In this case, following a formal request to the US NAO, we obtained a copy of the decision for the purpose of this research.

${ }^{44}$ Cummings (2006) notes that this well organized effort was led by the Coalition for Justice in the Maquiladoras, in collaboration with lawyers and law students at the International Human Rights Clinic at St. Mary's Law School (San Antonio) and the Columbia Law School International Human Rights Clinic. p. 84.
} 


\section{B. AdAPtive LAWYERING StRATEgiES IN CHALLENGing CiRCUMSTANCES: TwO RECENT CASES}

\section{U.S. NAO 2005-01 MEXICAN LABOUR LAW REFORM}

This submission was filed by an attorney at the Washington Office on Latin America (WOLA) ${ }^{45}$ on behalf of a network of twenty-two labor unions from Mexico, Canada and the United States. This submission was filed on February 17, 2005, but its review was declined by the US National Office on February 21, 2006. However, by the date the US NAO declined to review this complaint, the Mexican government had dropped the bill from Congress.

The submission challenged the Mexican government for having proposed to the Mexican Chamber of Deputies a Labor Law Reform, socalled "the Abascal Project," that would allegedly violate the "central obligations of the NAALC, namely to 'provide high labor standards' and to 'strive to improve those standards." It was argued that the proposed law reform legalized systemic violations of worker rights to free association, the right to organize and bargain collectively, and other rights acknowledged in the Constitution, International Labor Organization (ILO) Conventions ratified by Mexico, and various sections of the NAALC. This submission highlights the fact that the proposed reform overlooked previous findings by the ILO, the United Nations High Commissioner for Human Rights (UNHCHR), and the US and Canadian NAO's regarding existing practices in Mexico that were in violation of international worker standards. It was argued in the complaint, that with this bill coming into force, not only would new restrictions be imposed on workers, but also that this law was legalizing or perpetuating existing practices of violation of labor rights, particularly, the lack of public registry of unions and no public access to contracts, lack of dispute resolution and denial of union registration, exclusion clause or the dismissal of workers for their support of a particular union, lack of secret ballots in union elections, the existence of union monopolies, and the failure to protect workers' rights to freedom

${ }^{45}$ WOLA was founded in 1974 . Is an organization dedicated to promoting human rights, democracy and social and economic justice in Latin America and the Caribbean, and throughout its history, WOLA has worked with civil society, organizations and government agents. At http://www.wola.org/index.php?option=com_frontpage\&Itemid=1 visited June 22, 2007. 
from sex discrimination and pregnancy based discrimination. It was alleged that the Abascal Project perpetuated practices that had been questioned in submissions US 940002, US 9702 and US 9703.

Clearly, this complaint marked a watershed in advocate's use of the NAALC to challenge broad-based labour market and social policy issues. That is, the submission directly addressed structural issues associated with North American economic integration and pointed to a central debate about flexibilization of the labor market in favor of the free trade agreement. (Federico Novelo Urdanivia: 2006) The argument was both more complex and challenging to frame than other complaints, as the impugned laws had not in fact yet been passed. It was also closely tied to an ongoing labour and social mobilization in Mexico against the proposed reforms.

Following the filing of this complaint, a press release and various protests were organized by the Mexican Unions and advocates. ${ }^{46}$ Although the US press did not show much interest in this case, organizations such as Human Rights Watch got involved in both the NAALC process and perhaps more importantly, in the political debate about the government bill by sending a letter to the Chamber of Deputes on February 9 of 2005, where this organization requested the rejection of the project, and a new law reform to change the deplorable situation of workers in Mexico. The arguments in the letter followed the same order and logic as those of submission US 2005-01. ${ }^{47}$ Canadian, US organizations, and even a US politician, Mary Kaptur, all wrote letters to the members of the Mexican Congress requesting the rejection of the project. ${ }^{48}$ Jeffrey Vogt, one of the US lawyers involved in drafting this complaint, suggested that a strong "legislative strategy" was a necessary part of this action. This view was echoed by Arturo Alcalde, a leading Mexican lawyer in the case who had been involved in several previous

${ }^{46}$ La Botz, Dan, "Mexican Labor Year in Review: 2005,” Mexican Labor, News and Analysis, January, 2006, Vol. 11, No. 1.

${ }^{47}$ Human Rights Watch, "Mexico: Propuesta a Reformas Laborales de Fox representaria duro golpe a los derechos laborales" Carta a la Camara de Diputados de Mexico, February 9, 2005, at http://hrw.org/spanish/docs/2005/02/09mexico10158.htm visited June 18, 2007.

${ }^{48}$ According to information provided by Arturo Alcalde, and Mexican lawyer, one of the leaders of the advocacy group. 
NAALC complaints: "The legal work could not be done in these actions, without the actions of activism; one cannot live without the other." In Alcalde's view, legal activism is a notion that involves the complete spectrum of socio-legal work, including education, organization and litigation. ${ }^{49}$

Following this approach, the transnational coalition of lawyers in association with the labor movement held meetings with members of Congress in both Mexico and the US to raise awareness and exercise political pressure to halt the approval of the reforms. The government withdrew the project before the NAO issued its decision not to accept the complaint. Although the reasons for the withdrawal were not made explicit, advocates credit the mobilization and legal activism on the part of the independent labour movement in Mexico, which was supported by the efforts of the transnational advocacy network in submitting and publicizing the complaint and the issues.

The network which undertook this case was a continuation of prior shared work on labour rights defense at both local and international levels. In this case, nine lawyers from Mexico and several from the US, several with previous experience in NAALC complaints, decided to work together toward filing the complaint. According to Alcalde, lawyers, academics, and independent union leaders in Mexico had worked on the issue for over a year prior to the creation of the network for this particular purpose. Groups allied with independent unions in Mexico had developed an alternative legislative proposal to counter the Abascal package, and some of that work became the basis for the NAALC complaint. In discussions with the US counterparts, a decision was made to go ahead with filing the complaint at the U.S. NAO, though media strategies were coordinated for both countries. While lawyers and union leaders from all three NAALC countries worked together throughout the process, the names of the Mexican lawyers involved did not appear on the complaint. Asked about the reasons for that, Arturo Alcalde indicated that: "This was not about our names or anyone's names for that matter. The important thing was the

${ }^{49}$ In the words of Arturo Alcalde, the work of a lawyer in this kinds of cases, as it has been performed by the Authentic Front of Labor (Frente Autencito del Trabajo) has been to defend the rights of the workers through "formacion, organizacion y litigio juridico." 
type of complaint; it was about denouncing the brutal violations against workers.”

2. MeXicAn NAO - 2005-1 - Rights of Migrant WORKERS UnDER H-2B VISA PROGRAM IN IDAHO

In April 2005, the U.S. H-2B Visa program became the subject of a public communication filed with the Mexican NAO on behalf of a group of migrant workers in Idaho. The complaint was initiated, drafted and filed by the Northwest Workers Justice Center (Attorney Michael Dale) in cooperation with Maria Andrade of the Andrade Law Office in Idaho, and Laura Abel and other attorneys from the Brennan Center for Justice of NYU School of Law. Important logistical support was provided by the AFL-CIO Solidarity office in Mexico City and a total of 9 organizations joined the petition..$^{50}$ Although the complaint was presented on behalf of sixteen migrant workers from Panama, Mexico and Guatemala, this was intended to at the macro level, affect public policy to cover migrant workers under visa $\mathrm{H}-2 \mathrm{~B}$ in the federal legal aid system and at the micro level of the NAALC, to obtained protection for fundamental, social and economic rights of the workers. The NAO office took over two years to respond to the complaint. Finally, on October 12, 2007, the Mexican office sent a letter requesting specific information from the US NAO about the ongoing situation of $\mathrm{H}-2 \mathrm{~B}$ visa workers. ${ }^{51}$

The H-2B Visa facilitates the entry of seasonal Mexican workers into the United States. The complaint alleged that migrant workers under the H-2B Visa program in Idaho were denied protection against forced

50 These organizations included Centro de Investigacion Laboral y Asesoria Sindical, A.C.; Frente Autentico del Trabajo; National Union of Workers (UNT); Red Mexicana de Accion Frente al Libre Comercio; Sin Fronteras, I.A.P.; Idaho Migrant Council; National Immigration Law Center; Oregon Law Center; and Pineros y Campesinos del Noroeste.

${ }^{51}$ Letter sent to the submitters of the complaint by Claudia Anel Valencia Cardona on behalf of the Mexican Secretary of Labor and Social Promotion, dated October 24 of 2007. Attached to this letter, a copy of the set of 69 thorough questions placed on the US Ministry of Labor was also sent. 
labour and minimum employment standards; had suffered employment discrimination including inequality in pay for women and men; and who had been exposed to occupational injuries and offered inadequate compensation for these injuries. $^{52}$ In March 2006, four additional Mexicans brought to the United States as temporary workers by an American company filed an addendum to the original petition alleging employment contract, wage and housing violations during their work in a corn packing operation in Olathe, Colorado. ${ }^{53}$

The issue raised by the petition, as yet untested under the NAALC, dealt with the inability of the migrant workers to secure free legal assistance to enforce their rights under U.S. labour laws. In Idaho, legal aid lawyers receive federal funding from the Legal Services Corporation (LSC) and lawyers receiving LSC funding are barred by federal law from representing several categories of immigrants, including those who are in the U.S. on H-2B Visas. ${ }^{54}$ This case tested a specific principle of the NAALC, which states in Article 4(d) that the United States must

4. enforce its laws in connection with NAALC labor principles requiring:

d) “[p]roviding migrant workers in [the United States'] territory with the same legal protection as [United States] nationals in

\footnotetext{
${ }^{52}$ Lawyers working for the following groups filed the complaint: the Northwest Workers' Justice Project, the Brennan Center for Justice at New York University School of Law, and Andrade Law Office. Sixteen migrant workers from Panama, Mexico and Guatamala were joined by nine U.S. and Mexican organizations in filing the complaint, including Centro de Investigacion Laboral y Asesoria Sindical, A.C.; Frente Autentico del Trabajo; National Union of Workers (UNT); Red Mexicana de Accion Frente al Libre Comercio; Sin Fronteras, I.A.P.; Idaho Migrant Council; National Immigration Law Center; Oregon Law Center; and Pineros y Campesinos del Noroeste.

53 "Latin American Temporary Workers File Complaint Regarding U.S. Noncompliance with International Law Regarding Access to Labor Rights Lawyers”, online: Brennan Center

$<$ http://www.brennancenter.org/programs/pov/immigrant_rights_immigrant_access.html $>$ (last accessed 17 May 2006).

54 "Fact Sheet: Complaint to Mexican Government Regarding Access to Labor Rights Lawyers for Temporary Workers in the U.S.” (13 April 2005), online: Brennan Center http://www.brennancenter.org/programs/pov/immigrant\%20rights/immigrantrights_latint empworkers_factsheet.pdf (last accessed 12 December 2005). [“Brennan Center”]
} 
respect of working conditions.”55

This case illustrated the difficulty migrant workers have in obtaining legal representation in the United States. This is particularly true in remote areas of states such as Idaho, where for a variety of factors including language barriers and funding limitations, qualified private legal assistance is not readily available. ${ }^{56}$ Nevertheless, the need for migrant workers to have access to proper legal representation is necessary to secure a variety of rights related to their status. Only through the legal process can migrant workers in the U.S. obtain a remedy under the federal legislation such as the Migrant and Seasonal Agricultural Worker Protection Act and litigation is much more likely to be successful when migrant workers, often unfamiliar with the U.S. legal system and the English language, are represented by legal counsel. ${ }^{57}$ However, as of April of 2006 the Idaho state government had not addressed the lack of legal representation issue raised by the complaint, nor have any modifications been made to state laws to address the issue.

In this case, like the previous one, the filing of the complaint was accompanied by an extensive publicity and lobbying strategy both the US and Mexico. Independent unions from Mexico played a key role, sponsoring a press conference in that country, while the U.S based lawyers also issued a press release. Since the filing date, advocates have held meetings, and continued sharing information and coordinating activities. Although the response was quite delayed, advocates consider that the initial response of the Mexican NAO was promising. The sixty nine questions attached to the letter review the allegations of the complaint in some detail. Although well aware of the political implications this complaint has for both governments, the lawyers interviewed were of the view that this complaint had a good chance of proceeding at least to the stage of the issuance of a Report.

\footnotetext{
55 "North American Agreement on Labor Cooperation Between the Government of the United States of America, the Government of Canada and the Government of the United Mexican States” (13 September 1993), online: Commission for Labor Cooperation $<$ http://www.naalc.org/english/agreement.shtml> (last accessed 30 October 2005). ("NAALC")

${ }^{56}$ Brennan Center, supra note 54.

${ }^{57}$ Ibid.
} 
Although this case involved a new, rather than an established collaboration, the parties involved have built trust, worked together in the preparation of the draft and supported each other in understanding the legal, cultural and logistic dynamics of the case. Unlike the previous example, these lawyers did not have prior NAALC experience, but they did have previous contacts in the U.S. labor movement which facilitated the creation of the network. ${ }^{58}$

Two of the US lawyers ${ }^{59}$, having identified that the case of these particular workers in Idaho had potential to ground a good NAALC challenge, then traveled to Mexico City for a week. This period of testing the waters for a potential complaint included a series of eight to ten meetings with lawyers and unions. The lawyers also visited the NAO, to meet the staff and learn about the filing process. During these meetings, the lawyers shared their views, heard their counterparts and started the learning process, a process that was not always straightforward. As Dale stated "we had to begin by making sense of everything we were talking about with our counterparts" not only because of the difference in language but also because of the difference in culture and legal principles. Indeed, advocates from the two countries had different perspectives on some issues. While for the US lawyers legal representation and minimum standards were central to the petition, they found that access to a lawyer was a less urgent concern in Mexico. Rather, border security and immigration issues dominated the public policy agenda. Raising public awareness and concern around the poor treatment of legal visa workers who had already 'made it' into the U.S. was an unanticipated challenge. Even though in this case Mexican lawyers participated in discussions of the complaint and offered some assistance, the drafting and preparation was led by the US advocates.

\footnotetext{
${ }^{58}$ The Mexico City office of the AFL-CIO was acknowledged as particularly helpful in coordinating meetings with Mexican groups and providing logistical support for public outreach efforts such as press conferences.

${ }^{59}$ The lawyers who traveled to Mexico City were Michael Dale and Maria Andrade. Maria Andrade had previously represented these clients in a civil lawsuit against the employer for damages filed in the Federal District Court for the District of Idaho. All lawyers working on the complaint were experienced advocates for migrant workers rights.
} 
[VOL. 04 No. 05

\section{NORTH AMERICAN LABOUR ADVOCACY AND THE NAALC: SOME PRELIMINARY OBSERVATIONS}

Developments associated with deepening economic integration in North America have created many negative consequences for workers and created new obstacles to the struggle for workers rights. National governments are constrained in their ability to enact or enforce new protective legislation, while transnational sites such as the NAALC or the ILO are largely ineffectively for protecting or enforcing worker rights. There is not yet a comprehensive vision for labour law regulation, although it seems clear that what must emerge will incorporate both national and transnational actors and institutions. (Trubek, Mosher and Rothstein, 2000)

The 'transnational' element of the NAALC has never been its most powerful dimension, either normatively or institutionally. The scope and autonomy of the Secretariat of the Commission on Labour Cooperation has always been quite constrained, although it did some useful work in its first few years. However, for all practical purposes it now appears to have disappeared entirely as an independent entity, having been absorbed into the U.S. NAO. In any event, the functional cornerstones of the NAALC have always been the national administrative offices, each of which is housed within the labor ministry of its home country. Similarly, the normative purchase of the NAALC rests in the enforcement of domestic labour laws. To the extent that the NAALC is deeply embedded within national level norms and institutions, it is more accurate to describe the NAALC as a 'hybrid' or a 'tri-national' rather than a fully 'transnational' legal institution.

Although there is agreement among lawyers that some actions have somewhat benefited workers either directly through the decisions or through the collateral civil mobilizations and political pressure, it is also agreed that the NAALC is not fulfilling its substantive objectives. Minor advancements have been made in some areas. For instance, in Mexico it is now possible to select Union representatives by secret ballot, which has been a big gain for the independent unions. In many areas, however, small gains have been counterbalanced by larger set-backs as the perceived demands for greater flexibility in an increasingly competitive global 
environment facilitate the efforts of corporations to lobby largely sympathetic governments to erode remaining worker protections.

North American labour advocates, even though they increasingly occupy a defensive position, seeking to protect gains made in earlier eras, have hardly given up. In relation to the NAALC, although there have been disappointments both with the lack of attention to the process by governments and publics and a dearth of favorable results, they continue to explore the opportunities it might present. In this inhospitable context, complaints are increasingly located in the context of broader political campaigns - what we might say is that the political campaigns themselves increasingly have a transnational focus and dimension to them. In one instance, we have lawyers acting on behalf of Mexican migrant workers in Idaho seeking to educate and influence the Mexican public around the issues faced by workers across the border; during the time of a debate between the governments on the nature of a proposed guest worker program. And in another, we have U.S. based lawyers and organizations seeking to support mobilization against proposed regressive labour law reforms in Mexico by filing a complaint in the Washington NAALC office.

Further, these examples of international support and solidarity are not easily confined to the 'judicial' or 'quasi-judicial' arenas. That is, the advocates we spoke with in relation to these two complaints neither expected nor required any positive response from the NAO at all-their complaints were part of larger strategies involving public education on the issues, media, legislative lobbying and mobilization in more than one country. Their purposes had already been served by intervention they made into larger public policy debates through the drafting and filing of the complaints themselves. Moreover, it might be suggested that utility of the advocacy networks is not limited to the advancement of the NAALC claims, but that, insofar as they offer opportunities for ongoing education, mobilization and collaboration, they have become themselves a political site for social change.

Even this modest development in the direction of a transnational labour community is tenuous, however. The networks depend for their ongoing existence on the expertise and energy of a relatively small group of committed individuals who identify with the cause of the labor force 
and have seen the legal world as a vehicle for social justice. In many cases it was personal contacts or experiences that had mobilized these individuals to seek out this type of legal advocacy work; for one American lawyer, a particularly inspiring course in law school encouraged her to look to the international arena for opportunities to extend her advocacy, while for one Mexican lawyer, the experience of working in the border region mobilized her to advocate for workers rights in her subsequent legal career. Many of the lawyers interviewed observed that one of the best parts of the NAALC experience was getting to know and learning from their counterparts in another country. Most observed that, given the right sort of case, they would be interested in engaging in this sort of advocacy again. There were some important differences in the situation of the U.S. and Mexican lawyers that should be noted. While the US lawyers were funded through legal aid, law school clinical programs or NGO's, the Mexican lawyers in most cases take these cases on with no remuneration. The Mexican lawyers also assumed more personal risk associated with their advocacy work, including the risk of being intimidated or attacked. This last underlines the extraordinary level of commitment that is required to create and sustain these lawyering networks. 


\section{BIBLIOGRAPHY:}

Philip Alston (2006) "Core Labour Standards and the Transformation of the International Labour Rights Regime” in Virginia Leary nad Daniel Warner (eds.) Social Issues, Globalisation and International Institutions: Labour Rights and the EU, ILO, OECD and WTO

Mark Anner and Peter Evans, (2004) "Building Bridges across a double divide: alliances between US and Latin American labour and NGO's” 14 Development in Practice 34.

Camilo Borrero, "EL Derecho como Arma de la Reconstruccion Social" Revista El Otro Derecho, ILSA, Bogota, (1995), p. 23

Scott Cummings, (2006) "The Internationalization of Public Interest Law" (manuscript).

Steve Charnovitz, (2006) "Nongovernmental Organizations and International Law” 100 American Journal of International Law 348.

Lance Compa (2006) "Labour Rights in the FTAA", Globalization and the Future of Labour Law, Craig and Lynk, eds. (Cambridge) pp. 245-273.

-(2001) “NAFTA’s Labor Side Agreement and International Labour Solidarity” Antipode 451.

Linda Delp, Marisol Arriaga, Guadalupe Palma, Haydee Urita, Abel Velensuela (2004) “NAFTA's Labour Side Agreement: Fading Into Oblivion? An Assessment of Workplace Health and Safety Cases. Report of UCLA Center for Labour Research and Education. (online).

Rainer Dombois, Erhard Hornberger, Jens Winter (2003) "Transnational Labour Regulation in the NAFTA-A Problem of Institutional Design? The Case of the North American Agreement on Labour Cooperatoin between the USA, Mexico and Canada" 19:4 International Journal of Comparative Labour Law and Industrial Relations 421.

Cynthia Estlund, (2002) "The Ossification of American Labour Law" Columbia Law Review. 
Robert G. Finbow (2006) The Limits of Regionalism: NAFTA's Labour Accord (Ashgate).

Jonathan Fox, (2000) "The World Bank Inspection Panel: Lessons from the First Five Years”, 6 Global Governance 279.

Jonathan Graubart (2005) "Politicizing a New Breed of Legalized Transnational Political Opportunity Structures: Labour Activists Uses of NAFTA's Citizen-Petition Mechanism.” 26 Berkeley Journal of Employment and Labour Law 97

Shereen Hertel (2006) "New Moves in Transnational Advocacy: Getting Labour and Economic Rights on the Agenda in Unexpected Ways" Global Governance 12:3 pp. 263-281.

Human Rights Watch, (2001) "Trading Away Rights: The Unfulfilled Promise of NAFTA's Labour Side Agreement”.

International Federation for Human Rights (2006) Report on Violations of Labour Rights in Mexico Report no 448/2 (dated April 2006).

Tamara Kay, (2006) "Legal Transnationalism: Transnational Law, Governance and Movement Building under NAFTA" American Journal of Sociology

Margaret Keck and Kathryn Sikkink (1998) Activists Beyond Borders: Advocacy Networks in International Politics (Cornell).

John H. Knox (2004) "Separated at Birth: The North American Agreements on Labour and the Environment" 26 Loyola International and Comparative Law Review 101.

Dan LaBotz and Robin Alexander (2005) "The Escalating Struggles over Mexico’s Labour Law” NACLA Report on the Americas 39:1 p. 16

Federico Novelo Urdanivia (2006) "El Dialogo Social en el Campo Mexicano)” Economia UNAM Vol. 4 num. 10 99-114. 
Jose Maria Laso Prieto, "Sobre la Teoria del Uso Alternativo del Derecho" in El Catoblepas, Revista Critica del Presente, Num. 67, Madrid, Espana, Septiembre 2007 p. 6

Cesar A. Rodriguez-Garavito (2005) “Global Governance and Labour Rights: Codes of Conduct and Anti-Sweatshop Struggles in Global Apparel Factories in Mexico and Guatamala” Politics and Society 33 203-233.

(2005a) “Nike's Law: The Anti-Sweatshop Movement, Transnational Corporations and the Struggle over International Labour Rights in the Americas” in de Sousa Santos and Rodriguez-Garavito, eds. Law and Globalization from Below: Towards a Cosmopolitan Legality (Cambridge Studies in Law and Society).

Monica Schurtman (2005) "Los Jonkeados and the NAALC: The Autotrim/Customtrim Case and its Implications for Submissions under the NAFTA Labour Side Agreement.” 22 Arizona Journal of International and Comparative Law 291.

Trubek, D.M. and Trubek, L.G. (2007) "New Governance and Legal Regulation: Complementarity, Rivalry and Transformation” University of Wisconsin Law School Legal Studies Research Paper Series, 1047, May 2007.

-(2005) "Hard and Soft Law in the Construction of Social Europe: the Role of the Open Method of Coordination” European Law Journal 11:3 pp. 343-364.

Trubek, Mosher, and Rothstein (2000) “Transnationalism in the Regulation of Labour Relations: International Regimes and Transnational Advocacy Networks” 25 Law and Social Inquiry 1187-1211.

David Trubek and Lance Compa (2005) “Trade Law, Labor, and Global Inequality” in ... 